\title{
Augmented Reality 3D untuk Pengenalan Organ Tubuh Manusia
}

\author{
Andani Achmad ${ }^{\mathrm{a}, 1, *}$, Zahir Zainuddin ${ }^{\mathrm{a}, 2}$ dan Muh Fadhil JR Husain ${ }^{\mathrm{a}, 3}$ \\ ${ }^{a}$ Universitas Hasanuddin, Jl. Poros Malino, Gowa, Sulawesi Selatan, Indonesia \\ ${ }^{1}$ andani@unhas.ac.id; ${ }^{2}$ zainuddinzahir@gmail.com; ${ }^{3}$ fadhil.rvl38@gmail.com \\ *corresponding author
}

\begin{abstract}
INFORMASI ARTIKEL
ABSTRAK

Dikirim : :04 November 2020

Diulas : 15 November 2020

Direvisi : 22 November 2020

Diterbitkan : 28 Desember 2020

Marker Augmented Reality 3D pada Aplikasi Pengenalan Organ Tubuh Manusia adalah untuk membuat model belajar menggunakan teknologi Augmented Reality guna menyampaikan informasi tentang Pengenalan Organ Tubuh Manusia yang lebih interaktif dan inovatif dengan Teknologi Augmented Reality

Kata Kunci:

3D Modelling

Organ Tubuh Manusia

Augmented Reality ke dalam satu aplikasi Android. Dalam mendukung penelitian ini digunakan Aplikasi Blender untuk pembuatan 3D Modelling dan aplikasi unity untuk pembuatan sistem yang di dukung dengan Bahasa Pemrograman C\#, Vuforia SDK dalam implementasi Augmented Reality. Hasil pengujian deteksi 3D marker oleh kamera dapat di simpulkan bahwa tiap objek 3D memiliki jarak deteksi yang berbeda-beda. Hasil pengujian Virtual reality menunjukkan bahwa semua fungsi yang di ujikan dapat berjalan sesuai keinginan.

Keywords:

3D Modelling

Human organs

Augmented Reality

ABSTRACT

3D Augmented Reality Marker in the Application of Recognition of Human Body Organs is to create a learning model using Augmented Reality technology to convey information about the introduction of human organs that is more interactive and innovative with Augmented Reality Technology into one Android application. In supporting this research, the Blender application is used for the manufacture of 3D modeling and unity applications for the creation of a system which is supported by the C \# programming language, Vuforia SDK in the implementation of Augmented Reality. The results of the 3D marker detection test by the camera can be concluded that each $3 \mathrm{D}$ object has a different detection distance. Virtual reality test results show that all the functions tested can run as desired.
\end{abstract}

This is an open access article under the $\mathrm{CC}-\mathrm{BY}-\mathrm{SA}$ license.

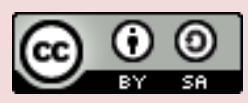

\section{Pendahuluan (bold, 10 pt)}

Teknologi diciptakan untuk mempermudah urusan manusia dan mempermudah segala sesuatunya. Berbagai macam jenis teknologi yang tidak terhitung jumlahnya dapat kita jumpai di zaman modern ini mulai dari smartphone, laptop, Gadget, dan sebagainya. Semakin canggih suatu zaman maka semakin banyak alat atau media canggih yang terus berkembang pesat dan semakin banyak pula orang menggunakannya untuk kebutuhan dalam mencari informasi dan memudahkan dalam pekerjaannya sehari hari [1]. Sebagian besar orang tua yang telah mengizinkan anak-anak mereka bermain gadget bahkan di usia mereka yang baru dua tahun. Bahkan saat ini anak-anak yang berusia kurang dari lima tahun pun lebih menyukai bermain dengan teknologi baru seperti playstation, game online, handphone, tablet ataupun ipad." Berdasarkan situasi tersebut, para pengembang aplikasi mencoba membuat aplikasi pembelajaran dan mengedarkannya. Hal itu terbukti berdasarkan hasil pencarian pada toko aplikasi Google Play, ditemukan beragam aplikasi dengan jumlah yang banyak. Pemanfaatan aplikasi tersebut pada pendidikan oleh orang tua terhadap anak dapat memberi efek ganda. Selain memberi efek positif sebagai media belajar anak, terdapat pula efek negatif dimana salah satunya, saat menggunakan gadget, anak cenderung tidak melakukan gerak badan. sensor motorik yang tidak digunakan, bisa saja mengakibatkan obesitas. Akibatnya, sensor motorik tidak digunakan oleh anak sejak kecil, bukan hanya keterampilan menulis saja yang menurun, tetapi akan membuahkan penyakit akibat tidak melakukan gerak motorik pada badan [1], [2][3]-[6]. Berdasarkan situasi tersebut, penulis ingin merancang aplikasi yang mendukung pembelajaran siswa yang memiliki fokus selain calistung pada perangkat smartphone, dimana penggunaannya dikombinasikan dengan media fisik berupa miniature. 
Dengan memanfaatkan aplikasi tersebut, anak tetap dapat berinteraksi dengan smartphone, mendapatkan layanan pemblajaran meskipun tanpa didampingi orang tua dalam penggunaannya.

\section{Metode}

\section{A. Augmented Reality}

Augmented Reality (AR) adalah teknologi yang menggabungkan benda maya 2 dimensi maupun 3 dimensi kedalam suatu lingkungan nyata 3 dimensi. Tujuan utama dari AR adalah untuk menciptakan lingkungan baru dengan menggabungkan interaktivitas lingkungan nyata dan virtual sehingga pengguna merasa bahwa lingkungan yang diciptakan adalah nyata. Dengan kata lain, pengguna merasa tidak ada perbedaan yang dirasakan antara AR dengan apa yang mereka lihat/rasakan di lingkungan nyata. Dengan bantuan teknologi AR (seperti visi komputasi dan pengenalan pola) lingkungan nyata disekitar kita akan dapat berinteraksi dalam bentuk digital (virtual). Informasi tentang objek dan lingkungan disekitar kita dapat ditambahkan kedalam sistem AR yang kemudian informasi tersebut ditampilkan diatas layer dunia nyata secara real-time seolah- olah informasi tersebut adalah nyata. Informasi yang ditampilkan oleh objek virtual membantu pengguna melaksanakan kegiatan-kegiatan dalam dunia nyata. Augmented reality, yang lebih dekat ke sisi kiri, lingkungan bersifat nyata dan benda bersifat maya, sementara dalam augmented virtuality, yang lebih dekat ke sisi kanan, lingkungan bersifat maya dan benda bersifat nyata. [7]-[12][1], [3], [4], [7], [8], [11]-[15].

\section{B. Pemodelan Tiga Dimensi (3D)}

Pemodelan Tiga Dimensi (3D) (3D modeling atau dikenal juga dengan meshing) adalah proses pembuatan representasi matematis permukaan tiga dimensi dari suatu objek dengan software tertentu. Produk hasil pemodelan itu disebut model 3D. Model 3D tersebut dapat ditampilkan sebagai citra dua dimensi melalui sebuah proses yang disebut 3D rendering. Model 3D direpresentasikan dari kumpulan titik dalam 3D, terhubung oleh berbagai macam entitas geometri, seperti segitiga, garis, permukaan lengkung, dan lain sebagainya. Berdasarkan hal tersebut, model 3D bisa dibuat manual (seperti seni memahat), secara algoritma (pemodelan prosedural), atau scanning. Hasil akhir dari citra 3D adalah sekumpulan poligon. Model dengan jumlah poligon yang lebih banyak memerlukan waktu yang lebih lama untuk di-render oleh komputer, karena setiap permukaan memiliki tekstur dan shading tersendiri. Semakin berkembangnya teknologi, model 3D semakin banyak digunakan. Dunia medis, menggunakan model 3D untuk menggambarkan detail organ tubuh. Industri perfilman menggunakan karakter atau objek yang dibuat komputer atau Computer Generated Imagery (CGI) yang merupakan model 3D [11].

\section{3Metode Perancangan Aplikasi}

Prosedur penelitian pada aplikasi Pengenalan Organ Tubuh Manusia pada Augmented Reality dapat dilihat pada Gambar 1.

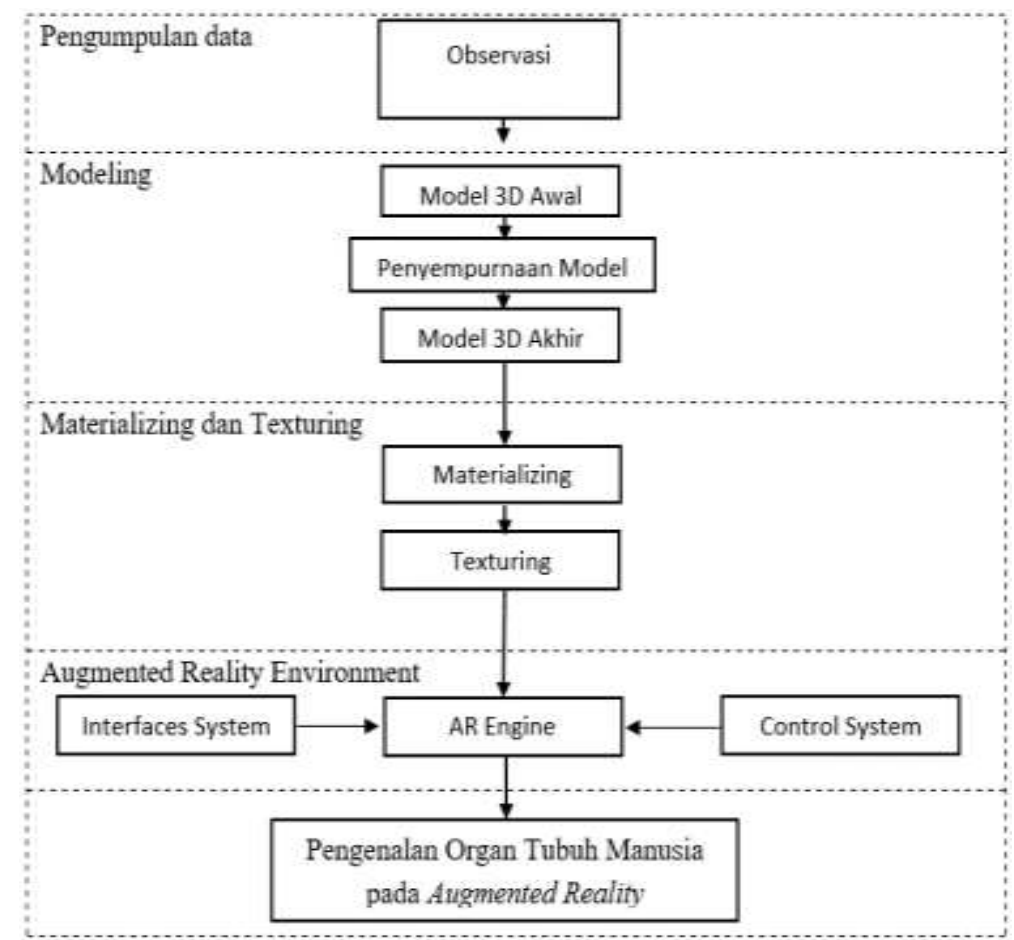

Gambar 1. Prosedur penelitian pada aplikasi Pengenalan Organ Tubuh Manusia pada Augmented Reality 
Flowchart untuk aplikasi mode augmented reality terlihat pada Gambar 2.

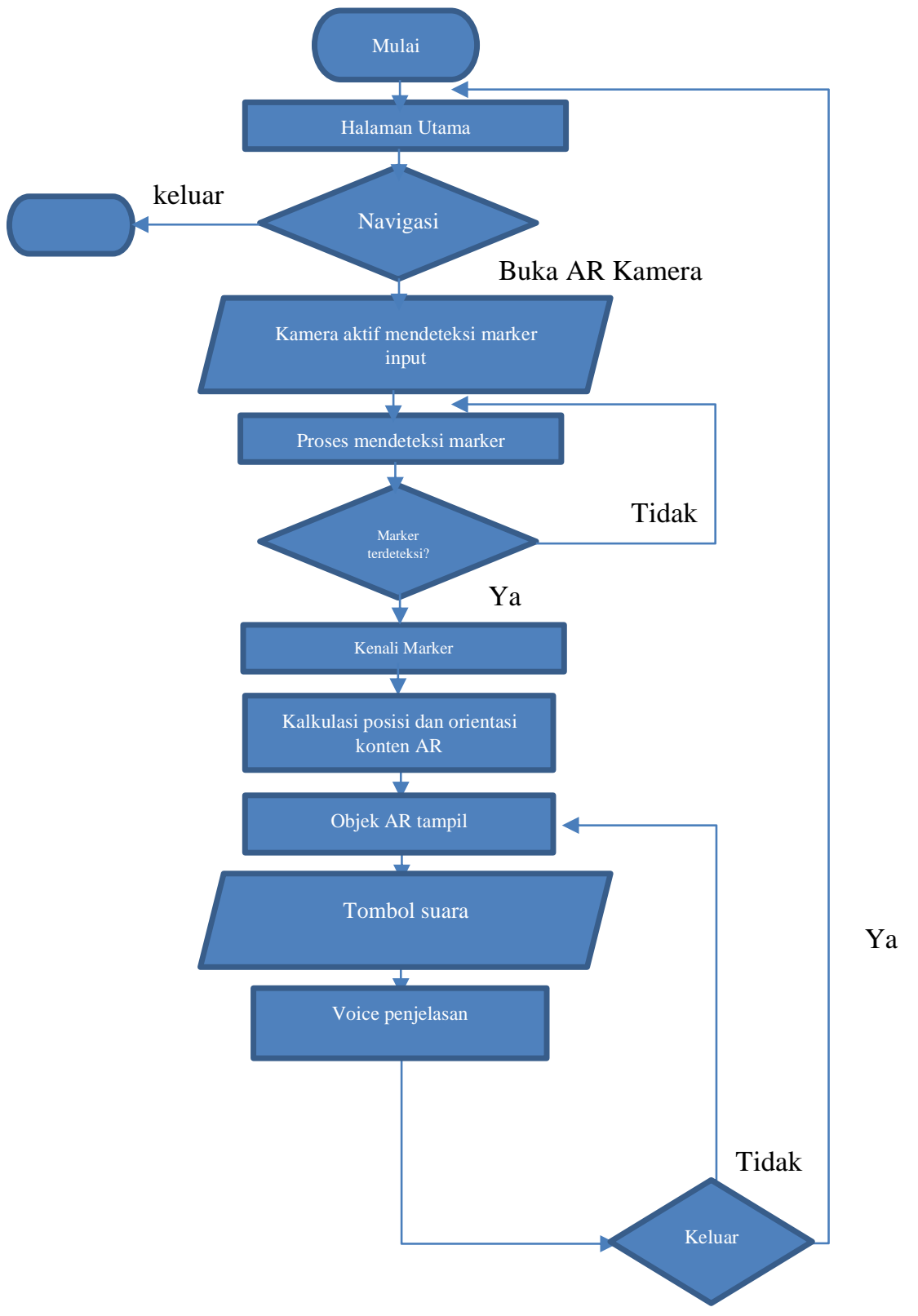

Gambar 2. Flowchart untuk aplikasi mode augmented reality

\section{Hasil dan Pembahasan}

\section{Pengumpulan data}

Tahap ini merupakan tahap pengumpulan data untuk membantu pembuatan objek 3D yang akan di buat dengan cara observasi di buku biologi sekolah dasar dan menengah untuk mengambil bahan pelajaran apa saja yang di ajarkan di sistem organ tubuh manusia. Di mulai dari pengambilan data fungsi organ tubuh manusia dan juga gambar organ tubuh manusia lalu kemudian di olah menjadi objek 3D dalam aplikasi Blender dan Unity 3D.

2. Objek $3 D$

Untuk pemodelan 3D aplikasi Blender yang digunakan telah mendukung pembuatan 3D model, mulai dari modeling dengan beberapa fungsi-fungsi dasar seperti scale, rotation, position, hingga proses texturing model menggunakan warna dasar ataupun material yang dapat di-import. Untuk pembuatan model penulis menggunakan objek-objek berupa Box, Cube, plane yang telah dilengkapi collision detection agar objek tidak dapat ditembus. langkah pertama yang dilakukan yaitu mentransformasikan gambar blueprint organ tubuh manusia. Dalam kasus ini pemodelan awal dalam mode wireframe 
seperti pada Gambar 3 untuk mengikuti bentuk dari gambar blueprint organ tubuh manusia dari data yang telah diambil sebelumnya.

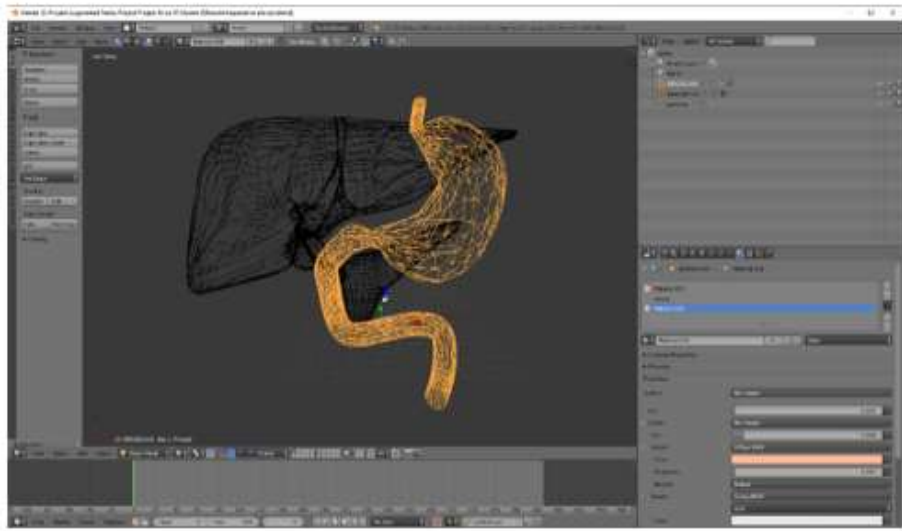

Gambar 3. 3D Hati dan Lambung Mode Wireframe

\section{Marker 3D di Vuforia}

Untuk membuat 3D marker masuk ke tab download lalu ke tools cari vuforia object scanner setelah itu pilih download apk. Vuforia object scanner ini digunakan untuk menscan object yang akan dijadikan marker (3D). Scan seluruh bagian objek (dari berbagai angle) untuk menscan titik-titik yang ada pada objek tersebut. Saat awal melakukan scan titik-titik pada objek belum terkenali seperti gambar sebelumnya. Harus melalukan scan hingga seluruh area terkenali seperti Gambar 4. Klik tombol ceklis untuk selesai.

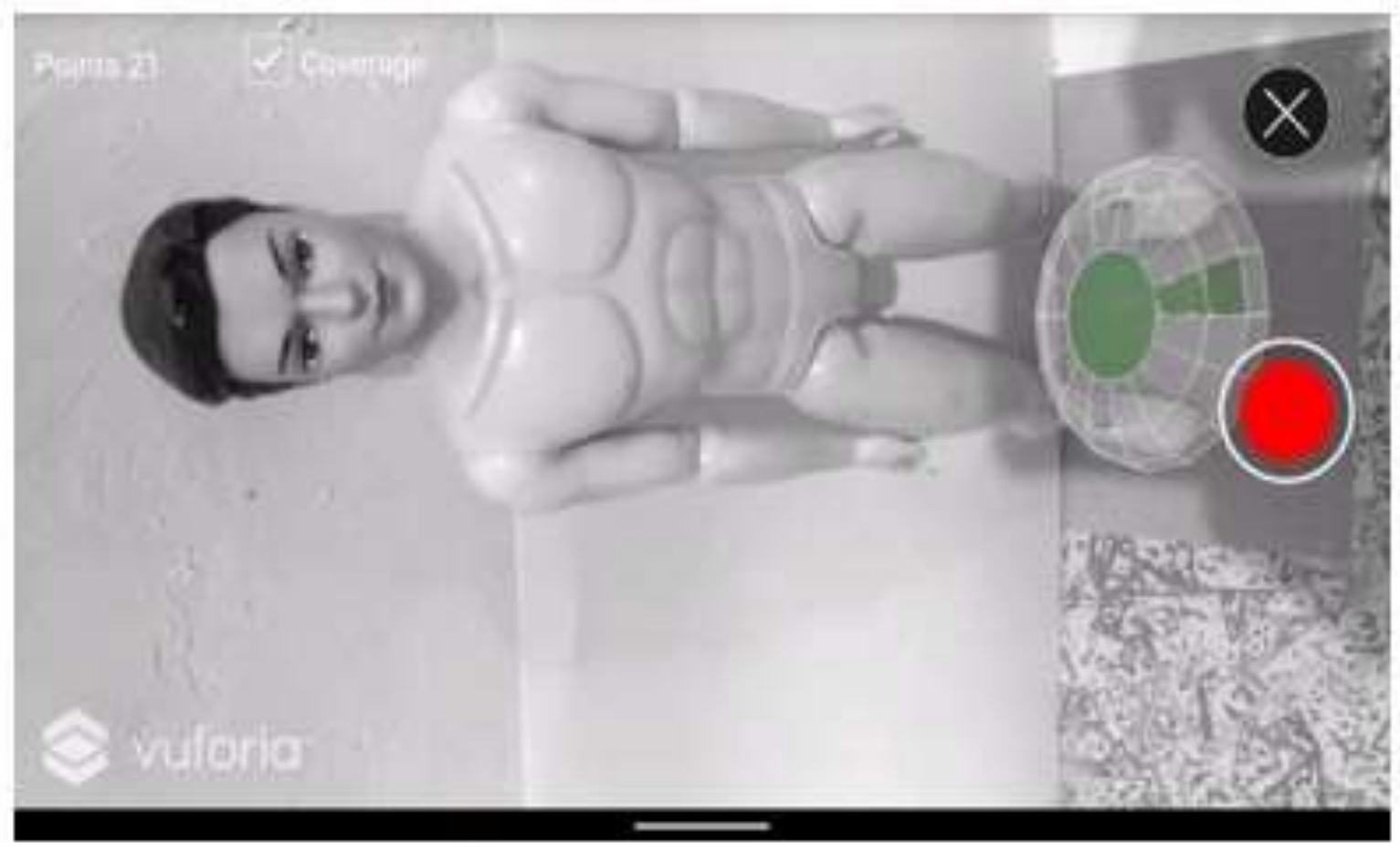

Gambar 4. Proses scan ke seluruh objek dari berbagai angle

File hasil scan akan berekstensi .od . Import file tersebut ke dalam vuforia. Masukkan nama database dan pilih tipe device, database yang ditambahkan akan ditampilkan pada target manager. Klik database yang dituju dan klik add target untuk memasukkan object 3D hasil scan yang akan dijadikan marker. Pilih 3D objek pilih unggah file gambar lalu masukkan ukuran panjang dan nama.

\section{Import 3D Model dari Blender ke Unity}

Langkah pertama yang dilakukan untuk mengimport 3D blender ke unity adalah mengeksport model dari blender dengan format file.fbx seperti pada Gambar 5. 


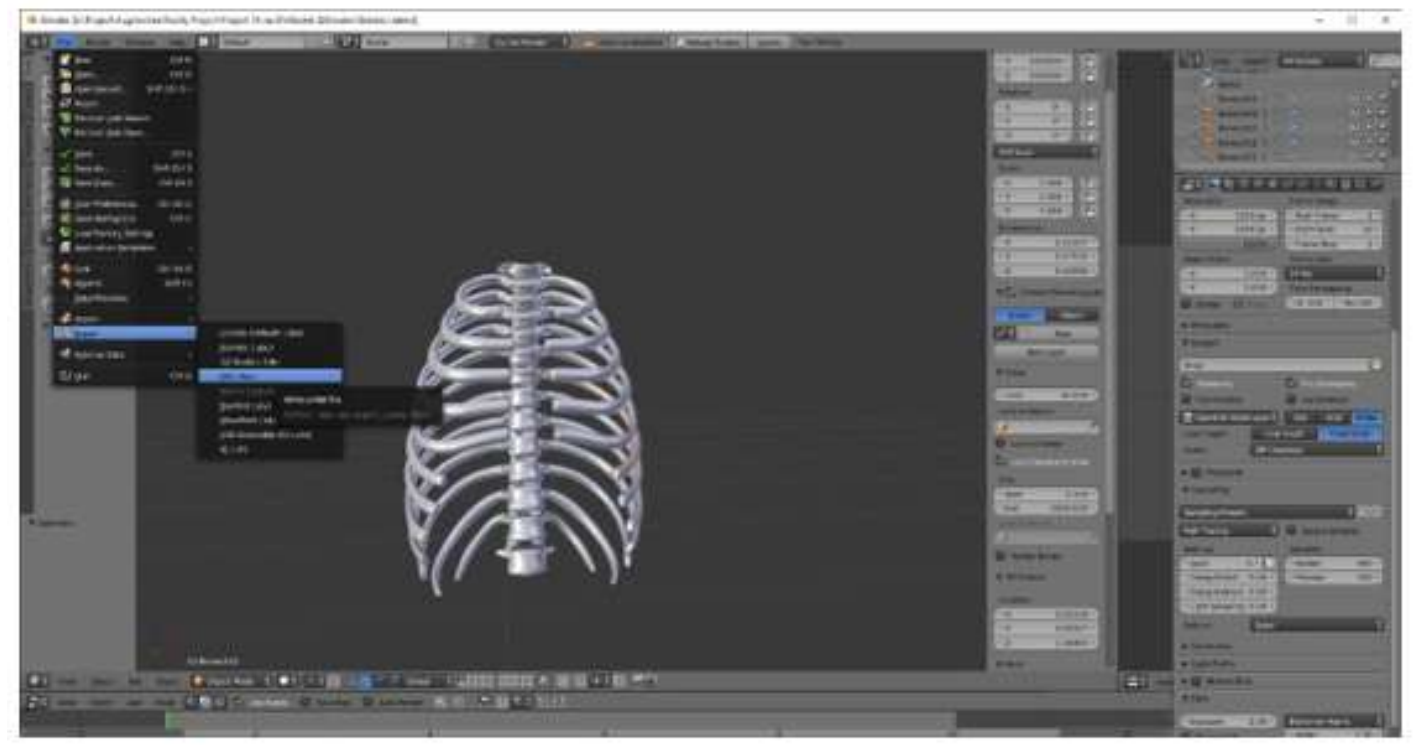

Gambar 5. Tampilan blender export 3D model

Selanjutnya, file yang telah tereskport tinggal di drag and drop ke aplikasi unity dan otomatis bisa digunakan sebagai model di unity. Lalu, menambahkan objek 3D dari model yang sudah di import dan menyusunnya seperti organ dan juga menambahkan tombol untuk berpindah scene ke organ yang ditujuh seperti pada Gambar 6.

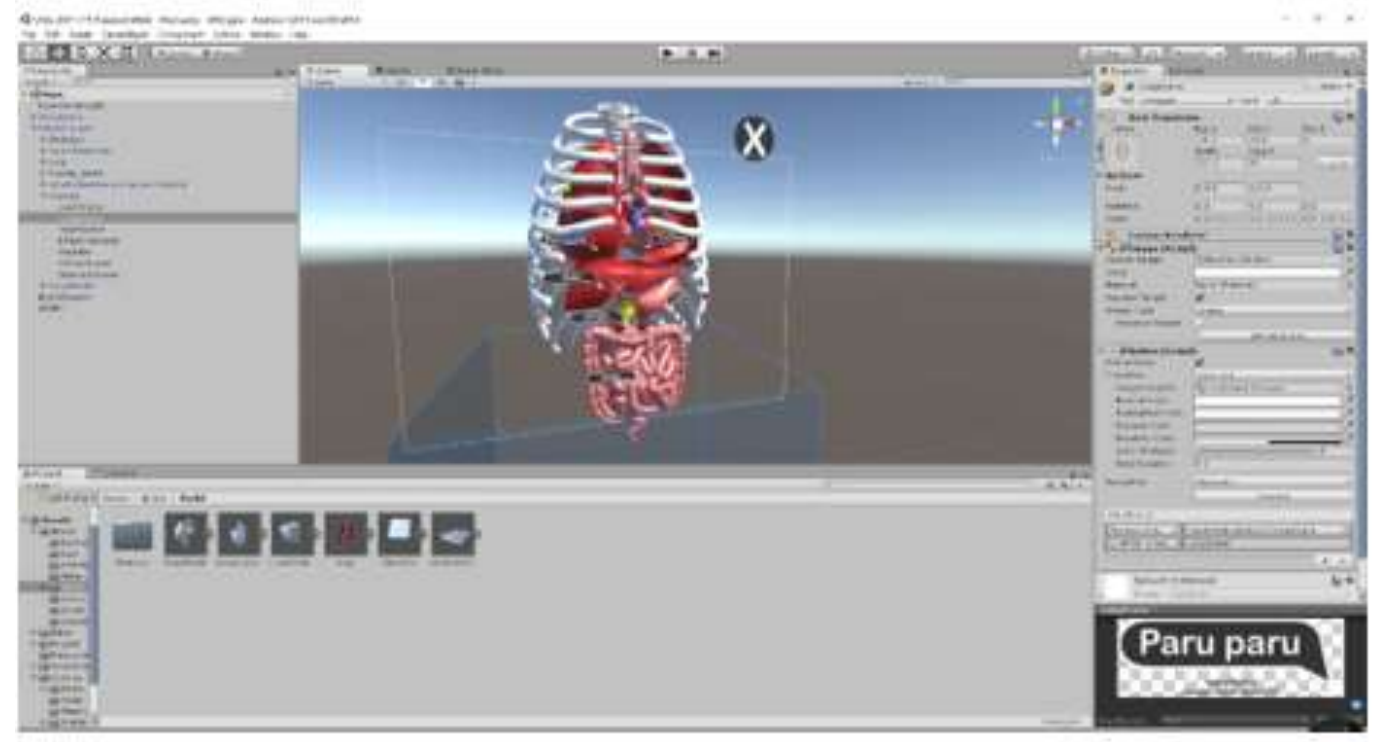

Gambar 6. Objek 3D yang sudah disusun di unity

\section{Audio ke dalam Project}

Untuk menambahkan audio pilih menu ke game object lalu pilih audio kemudian audio source. Kemudian rename audio source menjadi (nama organ) vo seperti jantungvo, selanjutnya drag audio file jantung ke menu inspector dan pilih audio clip. Untuk membuat fungsi tombol, pada bagian on click masukkan audio source JantungVO seperti Gambar 7.

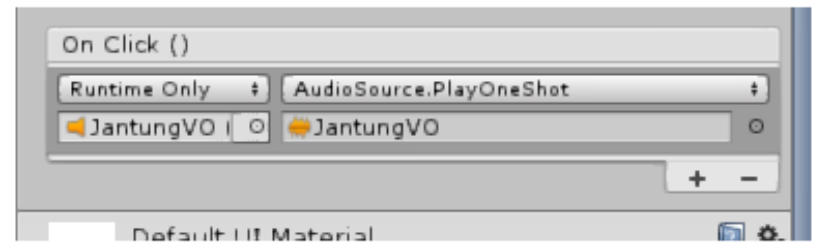

Gambar 7. Tampilan on click audio 
Setelah itu, masukkan semua fungsi tombol ke masing-masing tombol yang di buat sesuai dengan fungsinya seperti rotate, scale, dan exit.

\section{Interface}

Membuat tampilan main menu, buat kanvas kemudian masukkan background dan juga tombol dengan mengganti gambarnya dengan gambar yang telah di buat seperti pada Gambar 8 .

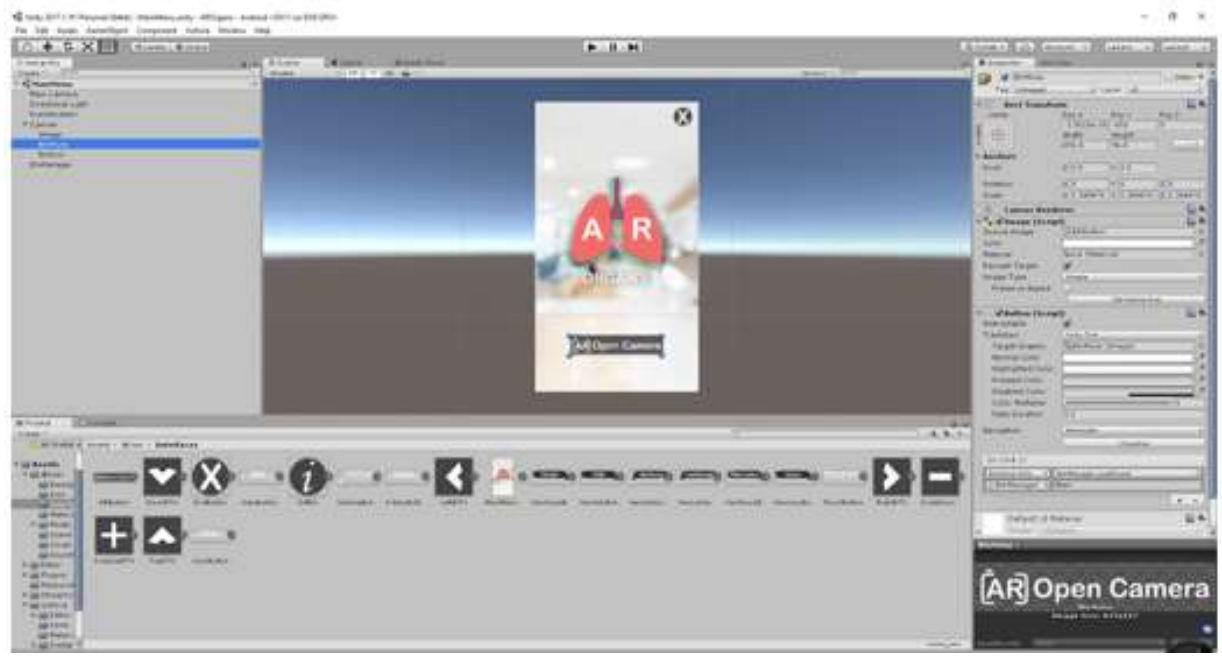

Gambar 8. Pembuatan main menu

Selanjutnya, klik menu file kemudian pilih build settings. Pada bagian scene in build centang semua scene yang ingin di render, pada bagian platform pilih Andorid kemudian klik tombol build.

\section{Membuat Animasi}

Selanjutnya untuk membuat animasi, pilih Animation di project window lalu pilih model di hierarchy window lalu atur scale $\mathrm{x}, \mathrm{y}$, dan $\mathrm{z}$ setelah itu atur per key frame sesuai yang di inginkan.

\section{Impelementasi Marker Augmented Reality 3D Pengenalan Organ Tubuh Manusia}

Aplikasi Pengenalan Organ Tubuh Manusia dapat membantu siswa dan guru sekolah untuk mempelajari organ tubuh manusia secara virtual. Aplikasi ini terdapat teknologi Augmented Reality, peneliti menggunakan 3D marker yang mampu memunculkan model 3D dari sistem organ tubuh manusia beserta keterangan di setiap organ yang ditampilkan dengan memanfaatkan fitur kamera pada smartphone.

\section{a. Tampilan Aplikasi}

Tampilan aplikasi dapat dilihat pada Gambar 9.

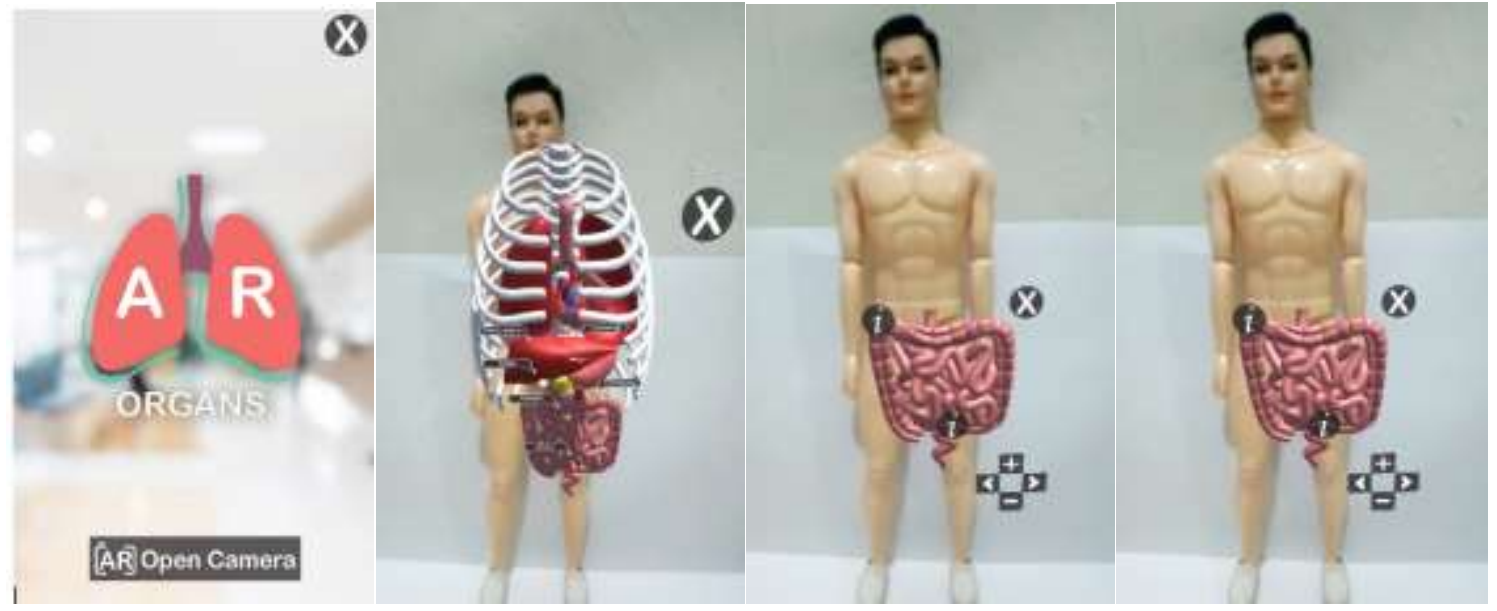

Gambar 9. Tampilan aplikasi AR Organ 


\section{b. Pengujian Aplikasi}

Pengujian akurasi adalah ukuran marker dan sudut pandang kamera terhadap marker dengan tujuan untuk mengetahui jarak minimum-maksimum pendeteksian marker berdasarkan pengaruh ukuran marker dan sudut pandang kamera x, y, dan z. Hasil pengujian dapat dilihat pada Tabel 1.

Tabel 1. Hasil pengujian akurasi marker dengan sudut pandang berbeda.

\begin{tabular}{|c|c|c|c|}
\hline \multirow{2}{*}{$\begin{array}{l}\text { Sudut Pandang } \\
\text { Kamera }\end{array}$} & \multirow[t]{2}{*}{ Marker } & \multicolumn{2}{|c|}{ Jarak Kamera dengan Marker $(\mathrm{cm})$} \\
\hline & & & Terjauh \\
\hline \multirow[t]{7}{*}{$\mathrm{X}($ Depan $)$} & Tampilan utama & 19 & 42 \\
\hline & Jantung & 12 & 34 \\
\hline & Paru-paru & 19 & 39 \\
\hline & Lambung & 18 & 39 \\
\hline & Usus & 17 & 34 \\
\hline & Hati & 15 & 32 \\
\hline & Ginjal & 16 & 32 \\
\hline \multirow[t]{7}{*}{ Y(Atas) } & Tampilan utama & 13 & 110 \\
\hline & Jantung & 12 & 100 \\
\hline & Paru-paru & 11 & 100 \\
\hline & Lambung & 13 & 95 \\
\hline & Usus & 11 & 100 \\
\hline & Hati & 12 & 98 \\
\hline & Ginjal & 12 & 97 \\
\hline \multirow[t]{7}{*}{ Z(Samping) } & Tampilan utama & 13 & 68 \\
\hline & Jantung & 12 & 57 \\
\hline & Paru-paru & 12 & 60 \\
\hline & Lambung & 12 & 60 \\
\hline & Usus & 12 & 63 \\
\hline & Hati & 12 & 65 \\
\hline & Ginjal & 13 & 60 \\
\hline
\end{tabular}

\section{Kesimpulan}

Pembuatan aplikasi AROrgans untuk sekolah menengah pertama menampilkan model 3D dari sistem organ tubuh manusia beserta penjelasan singkat dari tiap-tiap organ tubuh yang ada pada manusia dalam bentuk suara. Aplikasi dapat beroperasi pada perangkat mobile dengan minimum android berbasis android 4.4 (KitKat). Untuk AR menggunakan kamera smartphone android dengan menyorot marker yang telah ditentukan lalu menampilkan objek 3D beserta penjelasan. Hasil pengujian deteksi 3D marker oleh kamera dapat di simpulkan bahwa tiap objek 3D memiliki jarak deteksi yang berbeda-beda. Hasil pengujian Virtual reality menunjukkan bahwa semua fungsi yang di ujikan dapat berjalan sesuai keinginan.

\section{Daftar Pustaka}

[1] E. Damayanti, A. Ahmad, and A. Bara, "Dampak Negatif Penggunaan Gadget Berdasarkan Aspek Perkembangan Anak Di Sorowako," Martabat J. Peremp. dan Anak, vol. 4, no. 1, pp. 1-22, 2020, doi: 10.21274/martabat.2020.4.1.1-22.

[2] N. F. Mayenti and I. Sunita, "Dampak Penggunaan Gadget Terhadap Perkembangan Anak Usia Dini di PAUD Dan Tk Taruna Islam Pekanbaru,” Phot. J. Sain dan Kesehat., vol. 9, no. 1, pp. 208-213, 2018, doi: 10.37859/jp.v9i1.1092.

[3] A. R. Saputra, H. Tolle, and M. A. Akbar, "Pengembangan Media Pembelajaran Untuk Pengenalan Sistem Pencernaan Manusia Menggunakan Teknologi Augmented Reality,” J. Pengemb. Teknol. Inf. dan Ilmu Komput., vol. 3 No. 2, no. 7, pp. 7006-7013, 2019.

[4] Y. Indrawaty, M. Ichwan, and W. Putra, "Media Pembelajaran Interaktif Pengenalan Anatomi Manusia Menggunakan Metode Augmented Reality,” Inst. Teknol. Nas. Bandung, vol. 4, no. 1, pp. $57-68,2012$.

[5] M. Firdaus and N. Mas'ud, "Aplikasi Pengenalan Anatomi Tubuh Manusia Pada Sistem Kerangka, Sistem Pencernaan Dan Sistem Pernapasan Berbasis Teknologi Augmented Reality.” 2012.

[6] I. N. W. Kusuma, "Pembangunan Aplikasi Media Periklanan Arloji Menggunakan Augmented Reality Berbasis Android," 2014.

[7] R. D. A. Budiman, "Developing Learning Media Based on Augmented Reality (Ar) To Improve Learning Motivation," JETL (Journal Educ. Teach. Learn., vol. 1, no. 2, p. 89, 2016, doi: 10.26737/jetl.v1i2.45.

[8] U. M. W. Wahyudi and Y. B. Arwansyah, "Developing Augmented Reality-based Learning Media to Improve Student Visual Spatial Intelligence," Indones. J. Curric. Educ. Technol. Stud., vol. 7, no. 2, pp. 89-95, 2019, doi: 10.15294/ijcets.v7i2.36039. 
[9] A. Hamdani, A. Mahmudi, and K. Auliasari, "Augmented Reality Pengenalan Organ Dalam Manusia Menggunakan Metode Marker Berbasis Android," JATI (Jurnal Mhs. Tek. Inform. Augment., vol. 4, no. 1, pp. 1-8, 2020.

[10] M. Kristian, I. Fitri, and A. Gunaryati, "Implementation of Augmented Reality for Introduction To Android Based Mammalian Animals Using The Marker Based Tracking Method," J. Inform. dan Sains, vol. 03, no. 01, pp. 1-6, 2020.

[11] R. Rumajar, A. Lumenta, B. A. Sugiarso, and J. T. E. Unsrat, "Perancangan Brosur Interaktif Berbasis Augmented Reality," E-journal Tek. Elektro dan Komput., vol. 4, no. 6, pp. 1-9, 2015.

[12] D. R. Rahadi, "Pengukuran Usability Sistem Menggunakan Use Questionnaire Pada Aplikasi Android," J. Sist. Inf., vol. 6, no. 1, pp. 661-671, 2014

[13] N. H. Rohmah, Y. Sujana, and R. A. Yuana, "AR-KIO: Augmented Reality-based Application as Instructional Media on Input and Output Device Component.," IJIE (Indonesian J. Informatics Educ., vol. 1, no. 1, p. 143, 2017, doi: 10.20961/ijie.v1i2.12472.

[14] A. Fakhrudin, "The Implementation of Augmented Reality Technology in Teaching Natural Sciences to Improve Elementary Students' Learning Achievement," Al-Ta lim J., vol. 25, no. 1, pp. 13-21, 2018, doi: 10.15548/jt.v25i1.374.

[15] F. S. Irwansyah, Y. M. Yusuf, I. Farida, and M. A. Ramdhani, “Augmented Reality (AR) Technology on the Android Operating System in Chemistry Learning," IOP Conf. Ser. Mater. Sci. Eng., vol. 288, no. 1, 2018, doi: 10.1088/1757-899X/288/1/012068. 